\title{
DAKWAH DENGAN KENTHONGAN WONG BANYUMASAN
}

\author{
Imam Munawar \\ Fakultas Dakwah dan Komunikasi UIN Walisongo Semarang \\ Jln. Prof. Dr. Hamka Tambakaji, Kec. Ngaliyan, Kota Semarang \\ immoenawar@gmail.com
}

\begin{abstract}
This paper explains the phenomenon of local culture that exists in the Banyumas community in particular and the Banyumas residency in general. The phenomenon of da'wah through art and the linkage of local culture with the interacion between Islam and local culture in the form of art which developed by Banyumas community. The result is there is a relationship and interaction of Islam in a Kenthongan art performance with local culture in Banyumas. The variety and presentation of songs performed by one of the kenthongan groups in Banyumas shows a number of meanings and moral values about Islam which indirectly become a form of Islamic da'wah in the Banyumas community.
\end{abstract}

Keywords: Kenthongan, da'wah Islam and Banyumas Culture.

\begin{abstract}
Abstrak
Sebuah wacana yang menjelaskan tentang fenomena kebudayaan lokal yang ada di masyarakat wilayah Banyumas khususnya dan keresidenan Banyumas umumnya. Fenomena dakwah melalui seni dan keterkaitan budaya lokal dengan interaksi Islam, dalam sebuah seni yang dikembangkan oleh masyarakat Banyumas. Hasilnya ada hubungan dan interaksi Islam dengan dengan budaya lokal serta pesan moral dalam sebuah pementasan seni Kenthongan dengan budaya lokal di Banyumas. Bentuk variasi dan penyajian lagu yang dibawakan oleh salah satu grup kenthongan di Banyumas menunjukkan beberapa makna dan nilai moral tentang ajaran Islam yang secara tidak langsung menjadi sebuah bentuk dakwah Islamiyyah di masyarakat Banyumas.
\end{abstract}

Kata kunci: Kenthongan, dakwah Islam dan Budaya Banyumas 


\section{A. PENDAHULUAN}

Indonesia adalah negara kepulauan terbesar di dunia yang terkenal dengan keragaman agama, bahasa, suku bangsa dan kebudayaannya. Kebudayaan adalah kebiasaan yang sudah mendarah daging dan bersifat turun temurun dalam suatu suku bangsa. Pada hakikatnya kehidupan manusia merupakan bagian dari siklus kebudayaan, karena kebudayaan dalam arti luas menyangkut seluruh aspek kehidupan manusia itu sendiri.

Agama dan kebudayaan adalah dua hal yang saling berinteraksi dan saling mempengaruhi, karena pada keduanya terdapat nilai dan simbol. Agama mempengaruhi kebudayaan dalam pembentukannya, sedangkan kebudayaan dapat mempengaruhi sistem nilai dan simbol agama (Kuntowijiyo : 2001). Agama adalah simbol yang melambangkan nilai ketaatan kepada Tuhan, dan kebudayaan juga mengandung nilai supaya manusia dapat hidup di dalamnya. Agama dalam perspektif ilmu-ilmu sosial adalah sebuah sistem nilai yang memuat sejumlah konsepsi mengenai konstruksi realitas, yang berperan besar dalam struktur tata normatif dan sosial. Sedangkan budaya merupakan ekspresi cipta, karya, dan karsa manusia (dalam masyarakat tertentu) yang mengandung nilai-nilai religiusitas, filosofis, dan kearifan lokal (local wisdom).

Kehadiran Islam ditengah masyarakat yang sebelumnya sudah memiliki nilai-nilai budaya dan adat istiadat mengakibatkan terjadinya interaksi antar dua unsur budaya yang berbeda, yaitu di satu sisi Islam dan di sisi lain budaya lokal. Dalam proses interaksi tersebut, Islam dapat terakomodasi oleh nilai-nilai lokal. Pada sisi lain, Islam yang datang di tengah masyarakat yang telah memiliki sistem nilai berusaha mengakomodasi nilai-nilai lokal. Ini merupakan ciri khas ajaran Islam, yakni bersifat akomodatif sekaligus reformatif terhadap budaya maupun tradisi yang ada tanpa mengabaikan kemurnian Islam itu sendiri. Al Qur'an sendiri menyatakan bahwa tradisi orang-orang terdahulu seringkali menjadi pijakan bagi orangorang atau generasi berikutnya, "(agama kami) ini tidak lain hanyalah adat kebiasaan orang dahulu" dalam firman Allah Surat Asy Syu'araa' ayat 137 menyebutkan :

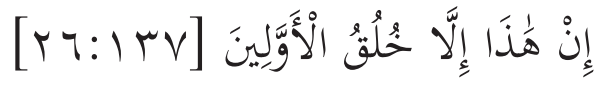

Artinya : (agama kami) ini tidak lain hanyalah adat kebiasaan orang dahulu.(Q.S. Asy Syu'araa'26: 137).

Ayat tersebut tampaknya di satu sisi memberikan isyarat pentingnya tradisi, tetapi di sisi lain kita tidak boleh terjebak pada sikap tradisionalisme. Interaksi Islam dengan budaya lokal pada suatu masyarakat mengalami bentuk hubungan yang beragam. Beragamnya bentuk hubungan tersebut tergantung dari penghayatan masyarakat terhadap ajaran Islam itu sendiri. Kedatangan Islam melalui dakwah tidak dilakukan dengan melangsungkan oposisi terhadap budaya lokal, tetapi mewarnai tradisi dengan spirit Islam. Masyarakat bahkan memiliki caranya sendiri untuk tetap menjaga agar budaya lokal tetap dilakukan dengan tanpa menciderai jiwa Islam, sementara Islam dijalankan dengan tetap menjaga harmoni tradisi masyarakat. Dengan demikian interaksi Islam dan budaya lokal dimaksud sebagai akulturasi nilai-nilai Islam yang terkandung dalam budaya lokal.

Dalam konteks budaya, keragaman kesenian yang ada dalam masyarakat lebih 
disebabkan oleh lapisan-lapisan budaya yang telah ada sejak keberadaan manusia di muka bumi ini. Demikian pula di Indonesia, kesenian dapat ditinjau dalam konteks kebudayaan maupun kemasyarakatan. Dari sisi konteks kemasyarakatan, kesenian yang tercipta pada kelompok masyarakat tertentu akan memperoleh dukungan dari masyarakatnya. Keberadaan kesenian dalam kehidupan masyarakat mempunyai fungsi yang berbeda menurut kebutuhan kelompok masyarakatnya. Pada kelompok masyarakat tertentu kesenian dapat berfungsi sebagai sarana ritual kehidupan religius, tetapi pada kelompok masyarakat lainnya kesenian dapat berfungsi sebagai hiburan. Dari kondisi masyarakat yang berbeda latar belakang budayanya ini, maka kesenian akan memiliki berbagai macam fungsi tergantung pada kebutuhan kelompok masyarakat pendukung kesenian tersebut.

Beranekaragam bentuk kesenian sebagai wujud proses kreatif masyarakat, hidup dan tumbuh subur di tengah kehidupan masyarakat dalam memenuhi kebutuhan berbagai aktifitas kehidupannya. Ragam bentuk kesenian tersebut selanjutnya diklasifikasikan sesuai dengan jenisnya, salah satunya kesenian yang hidup subur di masyarakat adalah jenis keseniantradisional. Hal ini sangat wajar karena kesenian tercipta oleh proses kreatif masyarakat secara kolektif dan selanjutnya digunakan untuk kebutuhan tertentu. Karena proses tersebut, selanjutnya bermunculan kelompok kelompok kesenian yang berkembang dalam kehidupan masyarakat. Kelompokkelompok tersebut berkembang dengan menyesuaikan perubahanyang terjadi dalamkehidupanlingkungannya. Peristiwa terbentuknya kesenian dalam kehidupan masyarakat sebagai proses kreatif dalam memenuhi kebutuhan rasa seni ini juga terjadi di Kabupaten Banyumas.

Keberadaan kesenian tradisional khususnya Kenthongan di Kabupaten Banyumas mendapat perhatian khusus dari masyarakat. Kesenian Kenthongan telah dikemas dengan tampilan yang menarik, dan dapat dinikmati oleh masyarakat lokal maupun interlokal. Hal tersebut berdampak pada ketertarikan masyarakat Banyumas khususnya untuk mementaskan kesenian grup Kenthongan dalam setiap even seperti hajatan orang nikahan, sunatan, lomba dan lainnya. Bahkan dalam acara HUT kabupaten Banyumas, Kenthongan selalu menjadi hal menarik yang diperlombakan sebagai hiburan khusus masyarakat Banyumas.

Setelah melihat uraian di atas, perlu adanya penelitian tentang interaksi Islam dengan budaya lokal dam kesenian Kenthongan yang ada di masyarakat Banyumas.

\section{B. METODE PENELITIAN}

Penelitian ini menggunakan jenispendekatan Kualitatif. Penelitian Kualitatif adalah pendekatan penelitian yang dimulai dengan asumsi, lensa penafsiran/teoretis, dan studi tentang permasalahan riset yang meneliti bagaimana individu atau kelompok memaknai permasalahan sosial atau kemanusiaan (Creswell, Jhon. W.: 2015).

Sumber data dalam penelitian initerbagi menjadi dua, yaitu sumber primer dan sumber sekunder. (1) sumber primer merupakan semua bahan tertulis yang berasal langsung atau asli dari sumber pertama yang membahas dan 
dikaji. Data dari observasi lapangan dan wawancara langsung terhadap tokoh masyarakat dan pegiat wisata Kandri. (2) sumber sekunder dimaksudkan sebagai bahan-bahan tertulisyang berasal tidak langsung atau asli dari sumber pertama yang membahas masalah yang dikaji. Data seperti artikel atau penelitian yang terkait dengan komunikasi lintas budaya ataupun antar budaya.

Selanjutnya teknik analisis data yang dilakukan ketika semua data sudah terkumpul dari proses pengumpulan data, kemudian disusun secara jelas. Analisis data adalah proses mencari dan menyusun data secara sistematis yang telah diperoleh dari pengumpulan data. Sehingga mudah dipahami apa yang telah menjadi temuan atau hasil dari pembahasan serta dapat diinformasikan kepada orang lain (Sugiyono: 2006).

Penelitian kualitatif bertujuan untuk memahami fenomena tentang apa yang dialami oleh subjek penelitian. Seperti perilaku komunikasi, motivasi, interaksi sosial, secara holistik dengan cara deskripsi dalam bentuk kata-kata dan Bahasa, pada konteks khusus yang alamiah dan dengan memanfaatkan berbagai konsep dan implementasinya (Sugiyono: 2005).

Peneliti melakukan analisis objek penelitian menggunakan analisis teori sistem sosial Talcott Parsons (1996) bahwa setiap masyarakat memiliki sistem sosial yang dapat digambarkan dengan AGIL.
Tabel 1: Sistem Sosial AGIL

\begin{tabular}{|c|c|c|}
\hline \multicolumn{2}{|c|}{ A } & I \\
\hline A & G & \\
\hline I & L & \\
\hline \multicolumn{2}{|l|}{} & \\
\hline G & L \\
\hline
\end{tabular}

Setiap bagian dari empat kotak itu terdapat sistem sendiri, yaitu agil. A adalah adaptation, dimana sistem beradaptasi dengan lingkungannya. G adalah goal attainment, dimana sistem memiliki tujuan-tujuan yang akan dicapai. I adalah integration, dimana setiap bagian sistem berhubungan satu dengan lainnya secara erat dan saling mendukung fungsi masing-masing. L adalah latency (pattern maintenance). Sistem juga secara laten memiliki kemampuan untuk mempertahankan pola-pola,aturan-aturan yang ada, bahkan memiliki kemampuan untuk memperbaiki sistem yang rusak apabila ada serangan dari luar sistem (Ritzer : 2014).

\section{HASIL DAN PEMBAHASAN}

1. Konsep Interaksi Islam

Manusia diciptakan berjenis lakilaki dan perempuan (berpasangan), membentuk komunitas menjadi beraneka ragam suku dan bangsa. Keragaman ini mencerminkan posisi manusia sebagai makhluk yang paling dinamis, kreatif dan inovatif bahkan yang paling cepat dalam hal reproduksi (Acep dan Sukriyadi : 2007).

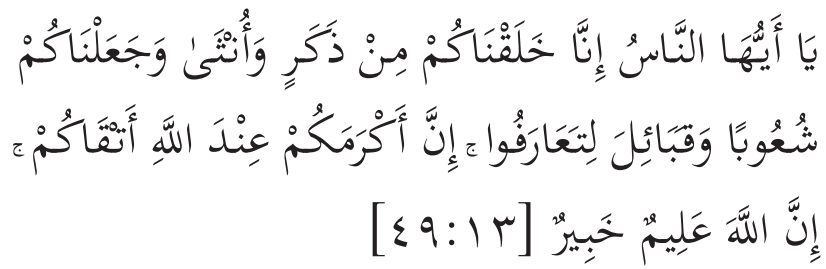


Hai manusia, sesungguhnya Kami menciptakan kamu dari seorang laki-laki dan seorang perempuan dan menjadikan kamu berbangsa-bangsa dan bersuku-suku supaya kamu saling kenal-mengenal. Sesungguhnya orang yang paling mulia diantara kamu disisi Allah ialah orang yang paling takwa diantara kamu. Sesungguhnya Allah Maha Mengetahui lagi Maha Mengenal. (Q.S. Al-Hujarat ayat/49:13)

Masyarakat, merupakan orangorang yang yang hidup bersama dan menghasilkan kebudayaan. Sosialisasi merupakan proses belajar untuk penyesuaian diri di masyarakat. Proses belajar untuk penyesuaian diri manusia berlangsung dalam proses yang lama dan bertahap sejalan dengan perkembangan pergaulan hidup manusia, yaitu mulai dari tahap anak-anak, dewasa, sampai tua (Ida Bagus Astawa : 2017).

Interaksi sosial berasal dari istilah bahasa Inggris social interaction yang berarti saling bertindak. Interaksi sosial merupakan hubungan sosial yang dinamis, bersifat timbal balik antarindividu, antarkelompok, dan antara individu dengan kelompok (Ida Bagus Astawa : 2017).

Islam dan kebudayaan dapat saling mempengaruhi karena keduanya terdapat nilai dan simbol. Faktanya dua hal tersebut perlu dibedakan, yaitu Islam adalah sesuatu yang universal, abadi (parennial) dan tidak mengenal perubahan (absolut) pada aspek tauhid. Sedangkan kebudayaan bersifat relatif dan temporer.

Islam sebagai agama universal merupakan rahmat bagi semesta alam dan dalam kehadirannya di muka bumi, Islam berbaur dengan budaya lokal suatu masyarakat (local culture), sehingga antara Islam dengan budaya lokal tidak bisa dipisahkan, melainkan keduanya merupakan bagian yang saling mendukung dan melengkapi. Agama bernilai mutlak, tidak berubah menurut perubahan waktu dan tempat. Berbeda dengan budaya, sekalipun berdasarkan agama, dapat berubah dari waktu ke waktu dan dari tempat ke tempat. Kebanyakan budaya berdasarkan agama, namun tidak pernah terjadi sebaliknya, agama berdasarkan budaya. Oleh karena itu, agama adalah primer, dan budaya adalah sekunder. Budaya dapat berupa ekspresi hidup keagamaan, karena ia subkordinat terhadap agama.

Sebagai suatu norma, aturan, maupun segenap aktivitas masyarakat, ajaran Islam telah menjadi pola anutan. Dalam konteks inilah Islam sebagai agama sekaligus telah menjadi budaya masyarakat. Di sisi lain budaya-budaya lokal yang ada di masyarakat, tidak otomatis hilang dengan kehadiran Islam. Budaya budaya lokal ini sebagian terus dikembangkan dengan mendapat warna-warna Islam seperti begalan, lengger dan juga Kenthongan Banyumas. Dengan demikian dapat dipahami bahwa Islam sama sekali tidak menolak tradisi atau budaya yang berkembang di tengah-tengah masyarakat Banyumas bahkan dalam penetapan hukum Islam dikenal salah satu cara melakukan ijtihad yang disebut urf, yaitu penetapan hukum dengan mendasarkan pada tradisi yang berkembang dalam masyarakat. Dengan cara ini berarti tradisi dapat dijadikan dasar penetapan hukum Islam dengan syarat tidak bertentangan dengan ajaran Islam yang tertuang dalam Al Qur'an dan Hadits Nabi Saw.

Proses Interaksi Islam dengan budaya lokal menunjukkan bahwa Islam 
dapat terakomodasi oleh nilai-nilai lokal dan pada sisi lain Islam berusaha mengakomodasi nilai-nilai lokal. Proses inilah yang disebut dengan pribumisasi Islam, yaitu bagaimana Islam sebagai ajaran yang normatif diakomodasikan ke dalam kebudayaan tanpa kehilangan identitas masing-masing. Pribumisasi Islam adalah kebutuhan bukan untuk menghindari polarisasi antara agama dan budaya (Abdurrahman : 2001). Pada konteks selanjutnya, akan tercipta polapola keberagamaan (Islam) yang sesuai dengan konteks lokalnya. Sehingga Islam tidak kaku dan rigid dalam menghadapi realitas sosial masyarakat yang dinamis.

2. Pola Interaksi Islam Dengan Budaya Lokal

Masyarakat merupakan bentuk riil dari elemen-elemen yang ada, kemudian dalam hal ini masyarakat merupakan pembentuk tindakan sosial dan definisi sosial. Oleh karena itu, manusia merupakan pencipta aktif realitas sosialnya sendiri. Teori interaksionisme simbolik adalah salah satu teori yang termasuk dalam paradigma definisi sosial. Tokoh paradigma ini adalah Max Weber (Syamsuddin : 2016).

Alasan mengapa Weber disebut tokoh paradigma sosial adalah karena ia bekerja menurut tradisi filsafat yang juga membentuk karya sosiolog yang kemudian Weber berkarya menurut tradisi filsafat Kant yang antara lain berarti bahwa ia cenderung berpikir dalam hubungan sebab akibat. Cara berpikir ini lebih dapat diterima oleh sosiolog yang kemudian, yang sebagian besar tak akrab dan tak menyenangi logika dialektika yang ditunjukkan karya Marx. Weber tampil dengan menawarkan pendekatan terhadap kehidupan sosial yang jauh bervariasi ketimbang Marx. Marx hampir secara total memasuki kajian ekonomi, sedangkan Weber tertarik pada berbagai aspek fenomena sosial (Ritzer : 2014).

Prinsip dasar teori interaksionisme simbolik yang diringkas oleh George ritzer dari pemikiran George Herbert Mead adalah sebagai berikut(Ritzer : 2014):

1) Tidak seperti binatang, manusia dibekali kemampuan untuk berpikir.

2) Kemampuan berpikir dibentuk oleh interaksi sosial.

3) Dalam interaksi sosial, manusia mempelajari makna dan simbol uamg memungkinkan mereka menggunakan kemampuan berpikir mereka yang khusus itu.

4) Makna dan simbol memungkinkan manusia melakukan tindakan khusus dan berinteraksi.

5) Manusia mampu mengubah arti dan simbol yang mereka gunakan dalam tindakan dan interaksi berdasarkan penafsiran mereka terhadap situasi.

6) Manusia mampu memodifikasi dan mengubah, sebagian karena kemampuan mereka berinteraksi dengan diri mereka sendiri, yang memungkinkan mereka menguji serangkaian peluang tindakan, menilai keuntungan dan kerugian relatifnya dan kemudian memilih satu di antara serangkaian peluang tindakan itu.

7) Pola tindakan dan interaksi yang saling berkaitan akan membentuk kelompok dan masyarakat.

Menurut Ritzer, kesimpulan utama yang perlu diambil dari substansi teori interaksionisme simbolik adalah bahwa kehidupan masyarakat itu terbentuk melalui proses interaksi dan komunikasi antar-individu dan antarkelompok 
dengan menggunakan simbol-simbol yang dipahami maknanya melalui proses belajar. Dalam perspektif interaksionisme simbolik, dakwah dengan pesan yang dibawanya dapat mengilhami pikiran anggota masyarakat untuk bersikap dan bertindak tertentu terhadap kejadian dan fenomena yang terjadi dalam masyarakat (Ritzer : 2014).

Antara agama dan budaya keduanya sama-sama melekat pada diri seorang yang beragama dan di dalamnya samasama terdapat keterlibatan akal fikiran mereka. Kebudayaan sangan berperan penting di dalam terbentuknya sebuah praktik keagamaan bagi seseorang atau masyarakat. Tidak hanya melahirkan bermacam-macam agama, kebudayaan inilah yang juga mempunyai andil besar bagi terbentuknya aneka ragam praktik beragama dalam satu payung agama yang sama (Khadziq : 2009).

Agama sebagai sebuah ajaran yang luhur dari Tuhan pada gilirannya juga akan membentuk sebuah tatanan budaya baru. Setiap agama hadir di dunia berfungsi sebagai pedoman dan peraturan bagi tata cara hidup umat manusia. Berbagai praktik agana sangat lazim muncul sebagai tradisi masyarakat, sehingga akan terbentuk tradisi agama yang sangat kuat dan selalu terpelihara dengan baik dalam sebuah masyarakat. Masyarakat yang selalu mempertahankan tradisi agama sebagai bagian dari kehidupannya akan membentuk sebuah masyarakat yang religius. Di sini akan menjadi bukti, bahwa pada sisi lain, agama juga akan melahirkan sebuah kebudayaan baru. Oleh karena itu dapat dikatakan bahwa antara agama dan kebudayaan berhubungan sebab-akibat secara timbal-balik, satu dengan yang lain saling mempengaruhi.
Masuknya Islam ke Nusantara (Indonesia) dan dalam perkembangan selanjutnya telah terjadi interaksi budaya yang saling memengaruhi. Namun dalam proses interaksi itu, pada dasarnyakebudayaan setempat yang tradisional masih tetap kuat, sehingga terdapat perpaduan budaya asli (lokal) Indonesia dengan budaya Islam. Perpaduan inilah yang kemudian disebut akulturasi kebudayaan. Akulturasi adalah percampuran dua kebudayaan atau lebih yang saling bertemu dan saling memengaruhi atau proses masuknya pengaruh kebudayaan asing dalam suatu masyarakat, sebagian menyerap secara selektif sedikit atau banyak unsur kebudayaan asing itu (KBBI : 1990). Oleh karena itu, baik konflik maupun integrasi tidak pernah dapat berjalan secara sempurna. Dengan kata lain, dalam pertemuan dua budaya yang berbeda tidak semua unsur budaya yang masuk tertolak secara keseluruhan dan juga tidak dapat terintegrasi secara penuh. Di antara dua kutub tersebut dapat terjadi proses tarik menarik sehingga mendorong terjadinya kompromitas, yaitu adaptasi atau akomodasi dan asimilasi. Sebuah unsur budaya dalam proses interaksi akan tertolak, bila terjadi pertentangan yang sangat menyolok dengan nilai-nilai lokal. Namun, unsur-unsur yang bertentangan tersebut dapat diakomodasi, bila dimodifikasi agar sesuai dengan budaya yang berlaku. Dapat juga dilakukan reinterpretasi agar unsur-unsur baru tersebut dapat diterima. Hal tersebut dapat terjadi dalam sebuah interaksi, karena setiap kebudayaan mempunyai kemampuan untuk bertahan dan menyeleksi pengaruh budaya luar dengan bentuk penolakan atau mendiamkan, akomodasi, ataupun instegrasi budaya luar ke dalam budaya 
asli.

Secara sosiohistoris Interaksi Islam dengan budaya lokal terjadi dalam tiga pola penyebaran dan pembentukan formasi Islam yang terjadi di Asia Tenggara, yaitu pertama, pola Pasai adalah pola dimana Islam tumbuh bersama-sama dengan perkembangan pusat kekuasaan negara dan Islam menjadi landasan sosial politik negara, sebagaimana dijelaskan dalam hikayat raja-raja Pasai (T. Ibrahim A : 1997). Pola kedua dirumuskan berdasarkan kasus Malaka, Patani, Gowa-Tallo dan Ternate yang disebut sebagai pola Malaka, yaitu penyebaran dan penerimaan Islam melalui kekuatan magis atau yang lainnya terjadi melalui konversi pusat kekuasaan lokal ke dalam kekuasaan Islam. Dan pola ketiga adalah pola Jawa, yaitu penyebaran Islam terjadi melalui penaklukan pusat kekuasaan lokal (Majapahit) oleh Islam (Demak), termasuk Kerajaan Sriwijaya (Budha) di Sumatera Selatan (Taufik A. danSharon : 1989).

RealitasinteraksiIslamdenganbudaya lokal dalam suatu komunitas akan selalu unik. Karena, adanya akulturasi dengan budaya setempat (lokal) dalam pengertian bahwa religi tersebut membentuk sistem tersendiri berbeda dengan sistem dan cara yang terdapat pada masyarakat Islam lain. Kendati boleh jadi masingmasing komunitas memeluk agama yang sama, setiap daerah mempunyai sistem dan cara tersendiri serta mempunyai kekhasan keislamannya. Ketika Islam menjumpai varian kultur lokal, maka yang segera berlangsung ialah aneka proses simbiose yang saling memperkaya. Hal ini menggambarkan Islam selalu memiliki warna lokal ketika menghampiri sebuah komunitas.

\section{Budaya Lokal Kesenian Kenthongan}

Budaya adalah suatu konsep yang membangkitkan minat. Secara formal budaya di definisikan seagai tatanan pengetahuan, pengalaman, kepercayaan, nilai, sikap, makna, hirarki, agama, waktu, peranan, hubungan ruang, konsep alam semesta, objek objek materi dan milik yang di peroleh sekelompok besar orang dari generasi ke generasi melalui usaha individu dan kelompok. Budaya menampakkan diri dalam pola-pola bahasa dan dalam bentuk bentuk kegiatan dan perilaku yang berfungsi sebagai model-model bagi tindakan-tindakan penyesuaian diri dan gaya komunikasi yang memungkinkan orang-orang tinggal dalam suatu masyarakat di suatu lingkungan geografis tertentu pada suatu tingkat perkembangan teknis tertentu dan pada suatu saat tertentu (Deddy Mulyana dan Jalaluddin Rakhmat : 2006).

Budaya dan komunikasi tidak dapat dipisahkan oleh karena budaya tidak hanya menentukan siapa bicara dengan siapa, tentang apa, dan bagaimana orang menyandi pesan, makna yang ia miliki untuk pesan, dan kondisi-kondisinya untuk mengirim, memperhatikan dan menafsirkan pesan. Sebenarnya seluruh perbendaharaan perilaku kita sangat bergantung pada budaya tempat kita di besarkan. Konsekuensinya, budaya merupakan landasan komunikasi. Bila budaya beraneka ragam, maka beraneka ragam pula praktik-praktik komunikasi (Deddy Mulyana dan Jalaluddin Rakhmat : 2006).

Kebudayaan adalah hasil cipta, rasa, karsa, dan karya manusia dalam memnuhi kebutuhan hidupnya (Suranto : 2010). Kebudayaan ini telah mengalami proses perkembangan secara bertahap dan

ISSN : 2085-3521, E-ISSN : 2548-9054 
berkesinambungan yang kita konsepkan sebagai evolusi kebudayaan. Evolusi kebudayaan ini berlangsung sesuai dengan perkembangan budi daya atau akal pikiran manusia dalam menghadapi tantangan hidup dari waktu ke waktu. Proses evolusi untuk tiap kelompok masyarakat di berbagai tempat berbeda beda, bergantung pada tantangan, lingkungan dan kemampuan intelektual manusianya untuk mengantisipasi tantangan tadi (Herimanto dan Winarno : 2016).

Berbicara tentang kebudayaan tidak bisa terlepas dari peradaban karena kebudayaan merupakan prasyarat bagi pengembangan peradaban. Dalam bahasa Arab, peradabandimaknaisebagai(tsaqofah) dan madaniyah. Madaniyyah mempunyai makna sebagai segala bentuk materi (fisik) yang terindra dan terkait dengan kehiduapan perkotaan. Dalam kitabnya Nizham al-Islam, Syaikh Taqiyu Ad-Din AnNabhani membedakan antara hadharah dan madaniyah. Hadharah adalah sekumpulan mafahim (pemahaman, pandangan hidup) yang dianut dan mempunyai fakta tentang kehidupan, sedangkan madaniyah adalah bentuk-bentuk fisik dari benda-benda yang terindra dan digunakan dalam berbagai aspek kehidupan (Sulasman dan Setia Gumilar : 2013).

Adanya kebudayaan bermula dari kemampuan akal budi daya manusia dalam menanggapi, merespons, dan mengatasi tantangan alam dan lingkungan dalam upaya mencapai kebutuhan hidupnya. Dengan potensi akal dan budi inilah manusia menaklukan alam. Manusia menemukan dan menciptakan berbagai sarana hidup sebagai upaya mengatasi tantangan alam. Manusia menciptakan kebudayaan (Herimanto dan Winarno : 2016).
Kesenian yang ada di daerah Banyumas cukup beragam seperti Kenthongan atau tek-tek Banyumasan, Ebeg (Kuda Lumping), Calung, Lengger, Begalan dan kesenian lainnya. Namun saat ini hanya beberapa kesenian saja yang masih populer dan dilestarikan.

Menurut Yustina Hastrini dkk. dalam (Sejarah Perkembangan Ekonomi dan Kebudayaan di Banyumas Masa Gandasubrata Tahun 1913-1942), Lengger atau ronggeng merupakan kesenian yang melekat dengan budaya Banyumas. Mengenai bagaimana penari lengger atau ronggeng ini oleh Thomas Stamford Raffles dalam karyanya yang berjudul The History of Java dikatakan bahwa ronggeng merupakan gadis penari yang tidak jarang juga menjual jasa seksual dalam layanan mereka. Penari ronggeng digambarkan tidak mempedulikan moral dan nyanyiannya "kasar dan aneh", sehingga dianggap jijik oleh bangsa Eropa. Namun, kesenian ini selalu disukai dan disambut riuh tepukan dan tawa penonton pribumi lokal (Raffles, 1817: 342-344) (Yustina Hastrini : 2015).

Citra Lengger/ronggeng atau tayub sebagai salah satu seni budaya tradisional rakyat Banyumasan, di daerah asalnya sekarang bisa dikatakan 'hidup segan mati tak mau'. Para pelaku tari ini sudah semakin berkurang, dan yang masih ada pun sudah jarang mementaskan jenis tarian ini lagi. Secara umun, garis besar seni pertunjukkan tari ini terdiri dari tarian yang diiringi dengan tembang (nyanyian) dan instrumen gamelan. Yang khas dari tarian lengger/ronggeng Banyumasan adalah tidak diiringi oleh gamelan dari logam, tetapi oleh calung, yakni instrumen gamelan yang seluruhnya dibuat dari bambu wulung baik gambang, saron, 
gong maupun suling, kecuali kendhang (gendang) yang tetap terbuat dari kayu dan kulit sapi (Budiono Herusatoto : 2008).

Kata 'jemblung' dalam Kamus Dialek Banyumas -Indonesia berarti 'pertunjukkan seni tutur atau cerita wayang, legenda, babad, sejarah lokal dan sebagainya. Soedarsono menyebut jemblung sebagai pertunjukan resitasi wiracarita tanpa wayang dan tanpa gamelan yang di gemari oleh masyarakat Jawa Tengah bagian Barat.

Masyarakat Banyumas sendiri menggambarkan bahwa "nanggap dalang jemblung" yang dilakukan serba lesan (serba mulut) lebih, murah, meriah, kocak/ penuh humor dan memukau dibandingkan dengan naggap wayang kulit Purwa. Pertunjukkan bergaya pedalangan yang dilakukan oleh beberapa orang itu, satu orang bertindak sebagai dalang yang bercerita, seperti dalam dalang wayang kulit, namun tanpa perangkat kelir dan wayang dan juga tanpa diiringi oleh suara perangkat gamelan. Dalang bertutur dengan dengan segala ekspresinya, mimik muka (mata, mulut, dan nada suara), dan gerak tangan dan tubuhnya untuk mengekspresikan segala peran dan sifat dari tokoh-tokohnya dalan lakon yang didongengkan semalam suntuk, mulai pukul 21.00 sampai menjelang subuh/ pukul 05.00/pagi. Suara gamelan, seperti gendang, gong, saron, kenong, kempul, dan lain-lain yang mengiringi cerita, adalah juga suara mulut dari para niyaga, yang juga mengiringi sinden yang juga mendampingi sang dalang (Budiono Herusatoto : 2008).

Adapun Kenthongan atau tektek Banyumasan merupakan kesenian yang populer bagi kalangan masyarakat Banyumas saat ini selain Begalan, Ebeg
(Kuda Lumping), Calung, Lengger, dan kesenian lainnya merupakan beberapa kesenian Banyumas yang menjadi daya tarik masyarakat karena keunikan dan kejenakaannya (Slamet dan Supriyadi : 2007).

Manusia sebagai makhluk budaya tentunya harus mengerti apa maksud dari budaya itu sendiri. "Manusia adalah makhluk yang yang bekerja". Artinya, sebagai makhluk paradoksal, manusia itu bebas dan terikat, otonom dan tergantung, terbatas dan tidak terbatas. Dengan adanya filsafat Karl Marx secara tidak langsung manusia merupakan makhluk sosial yang memiliki budaya atau kebudayaan. Sebagai makhluk yang dinamis, manusia bebas dan bertanggungjawab, tetapi dalam kebebasan juga hadir suatu dorongan metafisika, suatu orientasi dasariah untuk menuju diri yang sejati. Manusia sebagai makhluk budaya adalah manusia yang berada pada siklus idea atau pengetahuan bersama yang menjadi acuan dalam melaksanakan aktivitas bersama, melahirkan materi kebudayaan bersama atau pribadi yang merupakan pengembangan dari dorongan budaya, di berbagai sektor kehidupan keagamaan, keilmuan, peralatan hidup, keorganisasian sosial, bahasa dan komunikasi, serta kesenian (Rusmin Tumanggor: 2014).

Kenthongan adalah permainan alat musik yang terbuat dari bambu. Kenthong adalah alat utamanya, berupa potongan bambu yang diberi lubang memanjang disisinya dan dimainkan dengan cara dipukul menggunakan tongkat kayu pendek. Menurut sejarah yang berkembang, alat komunikasi ini sudah ada sejak awal Masehi. Sejarah yang paling terkenal di masyarakat yaitu tentang seorang penjelajah legendaris 
dari Tiongkok yang bernama Ceng Ho yang melakukan perjalanan dengan misi keagamaan dan menemukan Kenthong yang kemudian digunakan sebagai media komunikasi ritual keagamaan. Penemuan Kenthong tersebut kemudian dibawa ke China, Korea, dan Jepang. Di Indonesia Kenthong tidak hanya ditemukan di Jawa Tengah tetapi juga di daerah lain, dan sejarah ditemukannya Kenthong di masingmasing daerah berbeda. Sebagai contoh, di Yogyakarta alat komunikasi Kenthong ditemukan pada masa Kerajaan Majapahit yang digunakan sebagai alat untuk mengumpulkan warga (Irma Tri Maharani : 2016).

Definisi yang diungkapkan oleh Kang Bowoyang merupakan pemimpin group Tek-tek atau Kenthongan Jalu Laras, bahwa Kenthongan adalah "alat musik tradisional khas Banyumas yang terbuat dari Bambu atau kayu. Pada awalnya Kenthongan merupakan alat tradisional yang digunakan oleh masyarakat sebagai alat komunikasi antar warga yang ada dan biasanya digantung di depan rumah masing masing, untuk saat ini hanya bisa ditemukan di pos kamling atau gardu masing masing warga."

Pada dasarnya, fungsi Kenthong yang paling utama adalah sebagai alat komunikasi jarak jauh bagi masyarakat yang tinggal di daerah pedesaan atau pegunungan. Selain alat komunikasi jarak jauh, Kenthong juga merupakan alat komunikasi satu arah. Yang dimaksud dengan alat komunikasi satu arah yaitu antara pengirim dan penerima informasi tidak dapat menjalin komunikasi yang berkesinambungan dengan alat yang sama. Saat teknologi informasi belum berkembang pesat seperti saat ini, Kenthong digunakan oleh penduduk desa yang melakukan ronda atau jaga malam di pos kamling untuk memberitahukan kepada penduduk sekitar tentang bagaimana keadaan lingkungan desa (Irma Tri Maharani : 2016).

Ada kesepakatan dalam masyarakat mengenai makna-makna dari pola bunyi pukulan Kenthong seperti yang diungkapkan oleh Kang Bowo. Pola pukulan Kenthong tertentu dimaknai sebagai berita akan adanya suatu kejadian. Berita yang dikirim melalui bunyi pukulan Kenthong merupakan tanda bagi masyarakat yang mendengar agar segera siaga dan waspada. Untuk mempermudah mengingat pola bunyi pukulan Kenthong, masyarakat Jawa membuat lagu dengan syair sebagai berikut (Wawancara langsung dengan Kang Bowo : 2019) :

\section{"Siji siji Rajapati \\ Loro-loro ana maling \\ Telu-telu omah kobong \\ Papat-papat banjir bandang \\ Kaping limane, kelangan kewan \\ Doro muluk tanda aman"}

Setiap syair dalam lagu tersebut memiliki arti yang menjelaskan mengenai pola bunyi pukulan Kenthong yang dapat dijabarkan sebagai berikut :

1) Rajapati (Kematian)

Pola bunyi pukulan Kenthong per satu kali disebut Rajapati. Pola pukulan Kenthong ini dilakukan saat penjaga malam atau ronda mendapat berita mengenai kematian di wilayahnya. Kenthong akan dipukul dengan irama satu kali pukul secara terus-menerus.

Pola pemukulan Kenthong Rajapati adalah - - - - (tek, tek, tek, tek, tek, tek, tek, tek). 
2) Ana Maling (Pencurian)

Pola bunyi pukulan Kenthong per dua kali dilakukan saat penjaga malam atau ronda mendapat berita mengenai adanya pencurian atau maling di wilayahnya. Kenthongakan dipukul dengan irama dua kali pukul secara terus-menerus.

Pola pemukulan Kenthong ini adalah $\cdots \cdots \cdots($ tek tek, tek tek, tek tek, tek tek).

3) Omah Kobong (Kebakaran)

Pola bunyi pukulan Kenthong per tiga kali dilakukan saat penjaga malam atau ronda mendapat berita mengenai adanya kebakaran yang terjadi di wilayahnya. Kenthongakan dipukul dengan irama tiga kali pukul secara terus-menerus.

Pola pemukulan Kenthong ini adalah $\cdots \cdots \bullet \bullet \bullet-\cdots$ (tek tek tek, tek tek tek, tek tek tek).

4) Banjir Bandang

Pola bunyi pukulan Kenthong per empat kali dilakukan saat penjaga malam atau ronda mendapat berita mengenai adanya musibah banjir yang terjadi di wilayahnya. Kenthongakan dipukul dengan irama empat kali pukul secara terusmenerus.

Pola pemukulan Kenthong ini adalah

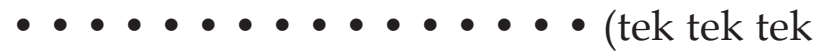
tek, tek tek tek tek, tek tek tek tek)

6) Kelangan Kewan (Kehilangan hewan)

Pola bunyi pukulan Kenthong per lima kali dilakukan saat penjaga malam atau ronda mendapat berita mengenai adanya hewan ternak yang hilang seperti sapi, kambing, ayam atau hewan lainnya. Kenthongan dipukul dengan irama lima kali pukul secara terus menerus.

Pola pemukulan Kenthong ini adalah (tek tek tek tek tek, tek tek tek tek tek, tek tek tek tek tek).

7) Dara Muluk (Tanda aman)

Pola bunyi pukulan Kenthong per enam kali dilakukan saat penjaga malam atau ronda merasa bahwa situasi di wilayah sekitar aman. Kenthongan dipukul dengan irama satu kali pukulan diselingi jeda dan diteruskan dengan delapan kali pukulan berturut-turut, lalu jeda dan diteruskan lagi dengan satu pukulan.

Pola pemukulan Kenthong ini adalah

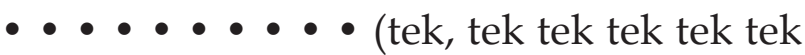
tek tek tek, tek).

8). Titir (Tanda panik)

Pola bunyi pukulan Kenthong Titir adalah jenis pukulan (tek, tek, tek, tek, tek, tek, tek, tek) dengan irama yang cepat dan terus menerus, menunjukkan tanda kepanikan. Pola ini biasa dipakai dalam kondisi panik, sebagai contoh ada orang yang berkelahi, ada hewan mengamuk, dan kondisi darurat lainnya yang membutuhkan bantuan atau kedatangan warga. Bunyi pukulannya $\bullet \bullet \bullet \bullet \bullet$ - (tek, tek, tek, tek, tek, tek, tek, tek).

Kenthong Titir dilakukan saat penjaga malam atau ronda mendapat berita mengenai adanya hewan ternak yang hilang seperti sapi, kambing, ayam atau hewan lainnya. Kenthongan dipukul dengan ritme cepat dan tidak ada irama atau hitungan tertentu.

Kesenian ini mulai muncul pada tahun 1997 di daerah Kabupaten Banyumas tepatnya di kawasan Tambakan, Desa Ajibarang Kulon. Awalnya di daerah tersebut hanya terdapat satu grup Kenthongan, namun karena musik ini cocok untuk mengiringi jenis lagu apa saja, maka kesenian Kenthongan pun sangat cepat berkembang dan menyebar luas ke seluruh pelosok Karesidenan Banyumas. 
Pada tahun 2004, seorang seniman bernama Edi Romadhon mengumpulkan 25 grup Kenthongan dengan jumlah total pemain 1050 orang untuk bermain bersama dalam Orkestra Kenthongan. Grup-grup Kenthongan tersebut kemudian berlatih bersama selama 3 bulan dan tercatat dalam Rekor MURI sebagai Orkestra Musik Kenthongan dengan pemain terbanyak. Sejak saat itu Kenthongan mulai menjadi ikon warga Karesidenan Banyumas (Irma Tri Maharani : 2016).

\section{Simbol Keislaman Dalam Kesenian} Kenthongan di Banyumas

Kebudayaan merupakan satu hal yang selalu melekat pada manusia dan masyarakat, yang berdampingan dengan satu hal lain, agama. Dalam kenyataannya, agama dan kebudayaan selalu melekat bersama-sama di dalam kehidupan manusia. Dalam wilayah interaksi dengan budaya Clifford Geertz menulis pengertian agama sebagai "(1) sebuah sistem simbol-simbol yang berlaku untuk (2) menetapkan suasana hati dan motivasimotivasi yang kuat, yang meresapi, dan yang tahan lama dalam diri manusia dengan (3) merumuskan konsep-konsep mengenai suatu tatanan umum eksistensi dan (4) membungkus konsep-konsep ini dengan semacam pancaran faktualitas, sehingga (5) suasana hati dan motivasimotivasi itu tampak khas realistis". Greets sangat menekankan perhatiannya pada dimensi budaya dari agama. Bagi Greetz, Kebudayaan dianggap sebagai susunan arti, atau ide, yang dibawa simbol, tempat orang meneruskan pengetahuan mereka tentang kehidupan dan mengekspresikan sikap mereka terhadapnya. Dengan demikian dapat dikatakan bahwa agama merupakan sistem kebudayaan dan oleh karena itu berarti pula sebagai sistem simbol (Khadziq : 2009).

Dalam kesenian yang ada dalam suatu daerah bahkan yang berkembang sampai saat ini memiliki makna atau simbol keislaman yang digambarkan dalam kesenian tersebut. Kesenian yang ada dalam kehidupan masyarakat bisa dimanfaatkan sebagai wasilah dakwah bagi para da'i dalam menyebarkan ajaran Islam.

Sunan Kalijaga memiliki kecerdasan dalam menganalisis masalah dakwah. Ketika masyarakat Jawa demikian gandrung pada kesenian wayang, ia tidak datang untuk melarang. Justru kegemaran masyarakat terhadap kesenian wayang menjadi inspirasi dakwah baginya. Maka dengan tanpa menyinggung atau menyakiti perasaan orang lain, Sang Sunan menawarkan budaya wayang dengan kemasan atau alur yang dapat memberikan pencerahan moral (Jhony Hadi Saputra : 2010).

Sahadatain, yaitu dikemas dalam "Jamus Kalimu Sodo", yang artinya dua kalimah Sahadat, dengan mudah dipahami oleh masyarakat karena menjadi bagian dari alur cerita, sehingga terbangun imajinasi mereka akan kehebatan pusaka itu. Selanjutnya sunan Kalijaga tinggal memberikan pemahaman bahwa dua kalimah Sahadat merupakan pasword untuk menuju keselamatan dunia dan akhirat.

Cara yang dilakukan Sunan Kalijaga tidak sia-sia. Pendekatan budaya itu membuahkan hasil yang signifikan terhadap perkembangan Islam, hingga kemudian Islam berkembang dengan pesat sampai ke pelosok Nusantara. Islam bukan lagi agama orang desa, Islam 
telah berhasil merambah sampai ke elit istana. Kesantunan Islam menjadi salah satu daya tarik setiap orang. Jasa sunan Kalijaga bukan hanya pada wayang dan gamelan, tetapi juga sangat berarti pada seni lainnya, seperti seni batik, ukir, pahat, suara, dan kesusastraan. Motif batik khas sunan Kalijaga adalah motif burung, yang dalam bahasa Kawi disebut dengan kukala. Kata tersebut diberi muatan etika dengan padanan arabnya quu qila yang berarti "jagalah ucapanmu" "peliharalah lisanmu" (Jhony Hadi Saputra : 2010).

Kenthongan berasal dari kata Kenthong yang diberi imbuhan an, yang berarti memainkan Kenthong. Pada zaman dahulu, Kenthong adalah alat komunikasi tradisional yang terbuat dari batang bambu atau kayu. Alat komunikasi tempo dulu yang digunakan dengan cara dipukul ini, sering dimanfaatkan oleh penduduk yang tinggal di daerah pedesaan dan pegunungan sebagai tanda alarm (pengingat), alat komunikasi jarak jauh, sandi morse, tanda adzan, maupun sebagai tanda bahaya.

Sebagai kesenian yang berkembang di Banyumas kesenian ini menggabungkan antara musik Kenthong dan tari-tarian gaya banyumasan. Definisi tari menurut Drs. Saimin Hp (1993:4), tari adalah ekspresijiwa manusia melalui gerak ritmis yang indah. Melalui tari, kita dapat mengekspresikan apa yang kita rasakan dengan gerakgerak estetis (indah). Indonesia dengan keanekaragaman budayanya memiliki berbagai macam gerak tari sebagai ciri khas dari masing-masing daerah, salah satunya adalah gerak tari gaya banyumasan. Gerak tari gaya banyumasan memiliki ciri khas gerak yang lincah, tegas dan patah-patah. Gerak tari inilah yang terdapat dalam kesenian Kenthongan.
Seiring pesatnya arus globalisasi, Kenthongan mulai mengalami perkembangan dengan sentuhan cipta, rasa dan karsa para seniman. Kenthongan yang awalnya terlihat sederhana dengan bunyibunyian yang monoton dan tidak memiliki nada dasar, sekarang terdengar lebih menarik karena dipadukan dengan alat musik lain dan juga tari-tarian tradisional maupun modern. Secara umum, kesenian Kenthongan di Kabupaten Banyumas dimainkan oleh sekelompok orang yang berperan sebagai pemusik dan penari.

Biasanya dalam sebuah grup tek tek atau Kenthongan beranggotakan 40-50 orang yang terdiri dari 10 - 15 orang penari, 20 40 orang pemain musik, dan sisaya official. Anggota grup Kenthongan ini memiliki latar belakang yang berbeda-beda, diantaranya adalah pelajar, mahasiswa, karyawan dan karyawati,menunjukkan makna bahwa derajat semua manusia sama di mata Allah, semua adalah ciptaannya tidak ada yang lebih tinggi melainkan Allah SWT. Grup yang dipimpin oleh Kang Bowo ini sering ditampilkan dalam berbagai acara dan disaksikan oleh berbagai kalangan masyarakat baik pejabat maupun petani. Musik yang dimainkan sangat bervariasi, begitu pula dengan gerak tariannya yang didominasi oleh gerak tari gaya Banyumasan yang terkenal dengan gerak lincah, tegas dan patah-patah.

Kesenian Kenthongan merupakan kesenian yang menjadi ciri khas Kabupaten Banyumas. Kesenian ini ditampilkan dalam bentuk kelompok yang beranggotakan 20 sampai 50 orang yang berperan sebagai pemusik dan penari. Dalam pertunjukannya, kesenian ini didukung oleh beberapa elemen penting, diantaranya yaitu : 
Group Kenthongan Jalu Laras sering mendapat panggilan untuk pementasan hajatan nikahan, khitanan, tasyakuran, lomba-lomba dan lainnya. Dalam setiap pementasan group ini bisa mementaskan 10 lagu minimal yang terdiri dari 5 lagu religi dan sisanya pop, campursari, lagu daerah, pop dan dangdut dalam sekali pementasan tergantung durasi waktu yang disiapkan oleh panitia atau penyelenggara. Setiap awal pembukaan pementasan, grup Jalu Laras selalu menyanyikan lagu religi dan sholawat tertentu dan memberikan gerakan penghormatan (gerakan tunduk menurunkan sebagian badan serta ada beberapayangsampai dudukmenunjukkan penghormatannya) kepada yang maha kuasa tentunya serta masyarakat yang menontonnya atau panitia serta juri lomba. Hal ini di lakukan sebagai upaya memohon doa agar di lancarkan dalam setiap pementasannya.

Setiap lagu dan gerakan yang di bawakan memiliki makna tersendiri selain sebagai hiburan semata, contoh bentuk penghormatan tersebut menggambarkan bahwa tidak ada yang lebih berkuasa selain Allah yang maha pencipta. Dalam gerakan dan tarian yang dipentaskan mereka akan menunjukkan gerakan rapi dan menyatu tidak tercerai berai.

Gerakan serta pertunjukkan yang dibawakan oleh group tek-tek atau kenthongan menunjukkan arti kekeluargaan, persatuan dan hidup rukun seperti ajaran Islam yang mengajarkan tentang keluarga serta persatuan. seperti dalam firman Allah Q.S. At- Tahrim ayat 06 sebagai berikut :

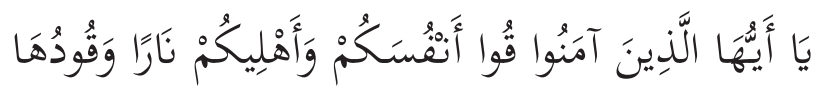

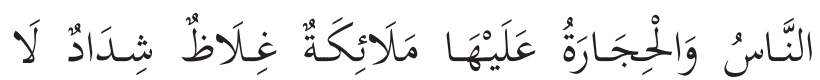

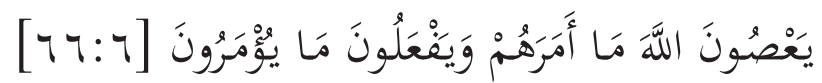

Hai orang-orang yang beriman, peliharalah dirimu dan keluargamu dari api neraka yang bahan bakarnya adalah manusia dan batu; penjaganya malaikat-malaikat yang kasar, keras, dan tidak mendurhakai Allah terhadap apa yang diperintahkan-Nya kepada mereka dan selalu mengerjakan apa yang diperintahkan.(Q.S. At- Tahrim ayat/66:06)

Makna yang di tunjukkan dari sebuah pementasan kenthongan juga berarti tentang sebuah kerukunan serta persatuan dalam sebuah hubungan masyarakat yang ditunjukkan dalam bentuk group kenthongan Jalu Laras yang tetap bersatu dan rukun walaupun mereka terdiri dari status sosial yang berbeda.

Firman Allah dalam Q.S. Al - Hujarat ayat 9 menyebutkan :

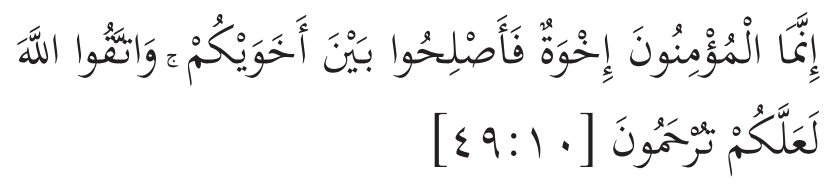

Orang-orang beriman itu sesungguhnya bersaudara. Sebab itu damaikanlah (perbaikilah hubungan) antara kedua saudaramu itu dan takutlah terhadap Allah, supaya kamu mendapat rahmat.(Q.S. Al-Hujarat ayat/49 : 9)

Makna makna yang ditunjukkan oleh pementasan group kenthongan Jalu laras ini lah sebuah bentuk dakwah dengan seni tradisional yang sudah ada sejak dulu namun masih tetap di lestarikan sebagai wadah dakwah bagi seorang da'i khususnya.

Proses Akuturasi kebudayaan merupakan dampak dari kenyataan lain bahwa setiap kebudayaan itu selalu mengalami persebaran atau difusi. Teori difusi muncul salah satunya sebagai kritik terhadap teori evolusi yang mendasarkan perubahan karena alam. Baik divusi 
maupun evolusi sama-sama rumpun dalam aliran historismus dalam ilmu kebudayaan. Ketika manusia muncul saat itu juga muncul kebudayaan. Kebudayaan asal itu selanjutnya berkembang, menyebar, dan pecah dalam berbagai kebudayaan baru karena pengaruh ruang dan waktu. Manusia makin lama makin berkembang, menyebar menjadi suku-suku dan bangsabangsa sehingga berpengaruh pada penyebaran kebudayaan mereka.

Dalam kehidupan bermasyarakat, antara agama dan kebudayaan hidup dan berkembang seiring dan sejalan dengan agama. Pola-pola dinamika yang dialami oleh keduanya juga tidak jauh berbeda. Ketika sebuah agama tertentu masuk ke dalam suatu masyarakat, budaya atau adat istiadat yang telah melekat seringkali dulit ditinggalkan. Budaya setempat berfungsi sebagai filter bagi masuknya budaya maupun agama baru dari luar; demikian juga sebaliknya agama yang telah mapan dalam sebuah masyarakat juga berfungsi sebagai filter bagi masuknya agama maupun budaya asing yang masuk dalam satu komunitas masyarakat. Di sini menjadi awal terjadinya singkretisme antara suatu agama dalam masyarakat dengan budaya setempat (Khadziq : 2009).

Dakwah Islam adalah salah satu bentuk aplikasi bagi setiap muslim perlu komunikasi dan interaksi (amarma'ruf). Bentuk interaksi dan komunikasi merupakan bentuk dasar dari akulturasi dan asimilasi. Dengan demikian hal ini memberi penjelasan bahwa dakwah merupakan akulturasi dan asimilasi dalam Islam. Kita tahu bahwa Islam pada awalnya diturunkan dalam konteks lokal, Makkah atau Arab yang kemudian berinteraksi dengan budaya lokal saat itu, hingga menjadi tradisi baru, tradisi Islam. Agama ini selanjutnya disebarluaskan, hingga sampai juga di Indonesia. Di Indonesia, seperti wilayah Jawa maupun wilayahwilayah lain sebelum mengenal Islam telah mempunyai budaya dan atau agama masing-masing. Ketika mereka mengenal Islam, agama dan budaya lama yang telah mengakar di masyarakat tentu tidak hilang begitu saja. Dalam konteks antar kelompok, dakwah sebetulnya merupakan sebuah proses komunikasi, transaksi ide masingmasing, anatara orang non Islam dengan orang Islam, yang berlanjut pada peristiwa konversi agama. Di sinilah asimilasi dan akulturasi dalam Islam melalui proses dakwah merupakan hal yang lazim.

Hubungan kenthongan dengan Islam sangat berkaitan, seperti halnya alat kenthongan yang dipadukan dengan bedug yang dipukul berirama dengan bedug saat waktu sholat tiba menandakan bahwa Islam mampu menerima akulturasi sebuah kebudayaan daerah pada masyarakat di Indonesia. Bedug yang saat ini digunakan di masjid seluruh Indonesia hampir semuanya menggunakan kenthongan untuk dipukul secara berirama ketika menjelang adzan dikumandangkan, hal inilah yang menjadi simbol keislaman di wilayah Indonesia.

\section{SIMPULAN}

Secara Teoritis Islam memang tidak mengajarkan seni dan estetika (keindahan), namun tidak berarti Islam anti seni. Ungkapan bahwa "Innalloha Jamilun yuhibbul Jammal" artinya Allah itu maha Indah dan mencintai Keindahan, secara tidak langsung Islam juga mengajarkan tentang kesenian. Seni dengan misi dakwah, yaitu seni yang menyampaikan makna pesan berupa nilai-nilai Islamiyyahyang 
di dalam interaksi sosialnya berusaha membawa audiens ke arah perubahan budaya (juga perubahan) yang lebih baik mendekati kebenaran syariat dan akidah Islamiyyah.

Kabupaten Banyumas memiliki beberapa kesenian yang menjadi hiburan tersendiri bagi mereka, seperti halnya Kenthongan yang masih eksis dan dipertahankan sebagai budaya dan seni lokal yang mereka miliki. Seperti penuturan Kang Bowo yang menjelaskan bahwa seni Kenthongan juga memiliki manfaat sebagai media dakwah Islamiyyah untuk menyebarkan ajaran Islam di tanah jawa khususnya Banyumas serta Indonesia secara umum.

Group kenthongan Jalu Laras yang ada di desa Tipar Kidul, kecamatan Ajibarang kabupaten Banyumas, dengan fungsi saat ini sebagai hiburan dapat disisipkan materi materi dakwah dengan bentuk lagu religi atau lagu lagu yang memiliki makna dan pesan moral yang dapat dijadikan ajaran bagi pemirsanya, hiburan kenthongan ini mampu berperan sebagai sebuah wadah dakwah bagi da'i maupun seniman lokal seperti KangBowo.

George H. Mead mendefinisikan tentang keistimewaan dan kemampuan dalam diri manusia, seperti maanusia memiliki kemampuan dan kapasitas umum untuk berfikir. Kemampuan manusia untuk berfikir dikembangkan sejak dini dalam sosialisasi anak-anak dan diperhalus selama sosialisasi di masa dewasa. Manusia mempunyai kemampuan istimewauntuk menciptakan isyarat yang berhubungan dengan suara, dan kemampuan ini menimbulkan kemampuan khusus untuk mengembangkan dan menggunakan simbol signifikan.
Islam yang mampu berdampingan dalam kebudayaan masyarakat ditunjukkan dalam berbagai bentuk kesenian maupun upacara adat yang ada pada masyarakat saat ini, seperti seni wayang kulit, wayang golek, upacara gerebeg syawal dan berbagai kesenian maupun upacara adat lainnya. Kenthongan yang ada di Banyumas juga dapat dibentuk dan dimanfaatkan sebagai media dakwah yang dikemas dalam nuansa seni dan hiburan yang memang diperlukan oleh masyarakat saat ini. Interaksi dan bentuk ajaran Islam dapat ditunjukkan dalam lagu-lagu religi yang dibawakan dalam setiap pementasan kenthongan.

Di Indonesia yang mempunyai jumlah penduduk muslim terbesar di dunia, kebudayaan dan akulturasi menjadi sangar kompleks. Seperti halnya budaya kenthongan di Banyumas merupakan sebuah bentuk akulturasi kebudayaan oleh masyarakat setempat dan kini dapat diterima dan berjalan selaras dengan ajaran Islam, bahkan digunakan sebagai media Dakwah Islam.

\section{E. IMPLIKASI DAN KETERBATASAN PENELITIAN}

Implikasi dari hasil temuan peneliti dalam penelitian ini adalah interaksi Islam dengan budaya lokal Banyumas yang terjalin dan beradaptasi sehingga menjadi sebuah media dakwah yang diminati dalam bentuk hiburan, serta menjadi sebuah wadah dakwah Islam yang dibutukan di era modern ini. Peneliti memberikan masukan dansaran untuk penelitian selanjutnya agar bisa melakukan penelitian terhadap budaya lokal yang terdapat di negeri Indonesia tercinta untuk melestarikan dan publikasi terhadap budaya atau tradisi 
lokal sehingga budaya yang diteliti ini akan dimengerti dan dikenal oleh khalayak umum.

\section{DAFTAR PUSTAKA}

\section{Buku}

Al-Qur'an dan Terjemahnya, Kementrian Agama RI.

Abdullah \& Sharon Shiddique (ed), Taufik. (1989). Tradisi Kebangkitan Islam di Asia Tenggara. Jakarta: LP3ES.

Aripudin, Acep. (2012). Dakwah antarbudaya, Bandung: PT Remaja Rosdakarya,

Aripudin, Syukriadi Sambas, Acep. (2007). Dakwah Damai, Pengantar Dakwah antarbudaya. Bandung : PT Remaja Rosdakarya.

Alfian, Ibrahim T. (1997). Pasai dan Islam, dalam Pasai Kota pelabuhan Jalan Sutra: Kumpulan Makalah Diskusi. Jakarta: Depdikbud.

Aw, Suranto. (2010). Komunikasi Sosial Budaya, Yogyakarta : Graha Ilmu,

Bagus Made Astawa, Ida. (2017). Pengantar Ilmu Sosial. Depok : PT Rajagrafindo Persada.

Creswell, Jhon. W. (2015). Penelitian Kualitatif $\mathcal{E}$ Desain Riset Memilih Diantara Lima Pendekatan. Yogyakarta: Pustaka Pelajar.

Setia Gumilar ,Sulasman. (2013). Teori-teori Kebudayaan dari Teori Hingga Aplikasi, Bandung : Pustaka Setia.

Irma Tri Maharani. (2016). Eksistensi Kesenian Kenthongan Grup Titir Budaya di Desa Karangduren, Kecamatan Bobotsari, Kabupaten Banyumas, Skripsi, Fakultas
Bahasa dan Seni Universitas Negeri Yogyakarta, Yogyakarta.

Sugiyono. (2005). Metode Penelitian Kuantitatif, Kualitatif dan RED, Bandung: Alfabeta.

Hadi Saputra, Jhony. (2010). Mengungkap Perjalanan Sunan Kalijaga. Yogyakarta : Pustaka Media.

Hastrini Nurwanti dkk. Yustina. (2015). Sejarah Perkembangan Ekonomi dan Kebudayaan di Banyumas Masa Gandasubrata Tahun 1913-1942 Yogyakarta : Balai Pelestarian Nilai Budaya BPNB.

Herimanto dan Winarno. (2016). Ilmu Sosial dan Budaya, (Jakarta : Bumi Aksara.

Herusatoto, Budiono. (2008). Banyumas, Sejarah, Budaya, Bahasa dan Watak. Yogyakarta : PT LKIS Aksara Yogyakarta.

Khadziq. (2009). Islam dan Budaya Lokal, Belajar Memahami Realitas Agama dalam Masyarakat, Yogyakarta: Teras.

Kuntowijiyo. (2001). Muslim Tanpa Mesjid: Essai-essai Agama, Budaya dan Politik dalam Bingkai Strukturalisme, Transendental. Bandung: Mizan.

Koentjaraningrat. (2002). Pengantar Ilmu Antropologi. Jakarta: Rineka Cipta.

Mahfudz, Ali. (1979). Kitab Hidayatul Mursyidin, Thuruqul Wa'dhi wal Khitobah, Kairo : Darul 'Itisomir.

Mulyana dan Jalaluddin Rakhmat, Deddy. (2006). Komunikasi Antarbudaya. Bandung : Remaja Rosdakarya.

Munawwir, Ahmad Warson. (1997). AlMunawwir, Kamus Arab - Indonesia, Surabaya : Pustaka Progressif.

Munir Amin, Samsul. (2009). Ilmu Dakwah, 
Jakarta : Amzah.

Rakhmat, Jalaluddin. (1994). Konsep-konsep Antropologis, Jakarta: Paramadina.

Ritzer, George. (2014). Teori Sosiologi Modern, Jakarta: Kencana.

Suwito. (2008). Islam dalam Tradisi Begalan, Yogyakarta : Grafindo Litera Media.

Slamet dan Supriyadi. (2007). Begalan Seni

Tari Upacara Penganten Masyarakat Banyumas: Surakarta: ISI Press,

Tim Penyusun Kamus Pusat Pengembangan dan Pembinaan Bahasa. (1990) Kamus Besar Bahasa Indonesia, Cet. II. Jakarta: Balai Pustaka.

Tumanggor, Rusmin dkk. (2010). Ilmu Sosial Dan Budaya Dasar. Jakarta: Kencana.

\section{Jurnal}

Irma Tri Maharani. (2016). Eksistensi Kesenian Kenthongan Grup Titir Budaya di Desa Karangduren, Kecamatan Bobotsari, Kabupaten Banyumas, Skripsi, Fakultas Bahasa dan Seni Universitas Negeri Yogyakarta, Yogyakarta.

Wawancara langsung dengan Kang Bowo, di rumahnya Jl. Proyek Tajum, Rt 04 Rw 01, desa Tipar Kidul, Kecamatan Ajibarang, Kabupaten Banyuma, tanggal 12 Juli 2019 pukul 20.00 